\title{
Eucalyptus: The Popular Exotic Tree Crop in Ethiopia
}

\author{
Abebe Birara Dessie*, Tadie Mire Abate and Taye Melese Mekie \\ Department of Agricultural Economics, College of Agriculture and Environmental Science, University of Gondar, Ethiopia \\ *Corresponding Author: Abebe Birara Dessie, Department of Agricultural Economics, College of Agriculture and Environmental Science, \\ University of Gondar, Ethiopia.
}

Received: May 16, 2019; Published: August 12, 2019

DOI: 10.31080 /ASAG.2019.03.0607

\begin{abstract}
An increasing in the demand of forest product such as wood for construction poles, timber, firewood, charcoal, fencing, posts, farm implements and source of income which makes Eucalyptus is the popular tree crop in across the tropics. Eucalyptus is a long and ever green tree which belongs to the family of flowering plants known as Myrtaceae. In Ethiopia, Eucalyptus is one of the most exotic tree species which introduced by Emperor Menelik II in 1895 in order to alleviate the shortage of firewood and construction wood in the capital city of Ethiopia. Currently, Eucalyptus is growing and expanding almost in all part of Ethiopia for satisfying the growing demand of forest product. Even though Eucalyptus provides various socio-economic benefits to most households', it has some negative impacts on soil nutrients, neighbour crops and water. However, the negative impacts of Eucalyptus are mainly results from poor management. Hence, there are no deep reasons to discard Eucalyptus plantation in Ethiopia. Generally, production and planting of Eucalyptus tree in the form of woodlot have a significant poverty alleviation role as a source of regular income, and improving most Ethiopian household's livelihood.
\end{abstract}

Keywords: Eucalyptus; Dilemma; Woodlot; Ethiopia

\section{Background}

Eucalyptus is an exotic and most popular tree species classified in Myrtaceae family [1]. It is a genus of more than 500 species and become the most planted genus of tree species in the world [2]. Although Eucalypts is a native of Australia, it is now widely and successfully planted in India, South Africa, Zimbabwe, Kenya, Uganda, and Tanzania [3]. According to Liu and Li, [4], the major Eucalyptus growing countries are: China (170 million ha); India (2.5 million ha); and Brazil (3.7 million ha) but 15 years ago Brazil has higher Eucalyptus plantation than others (Figure). Currently, more than 100 Eucalyptus species are grown in Africa, 70 of them found in Kenya [5] and about 55 cultivated in Ethiopia [6]. Forest plantation practices in Ethiopia are mainly exotic tree species with Eucalyptus covering the largest area of hardwood plantations (EPA, 2007). According to Kebebew and Ayele [7] growing Eucalyptus at farm level in the form of woodlot has becoming popular among smallholder farmer in Ethiopia. Eucalyptus species have been introduced in Ethiopia for satisfying the growing demand of wood for fuel, construction material and to reduce the pressure on the remaining natural vegetation [8]. In the country, it is largely confined to the highlands (1500-3200 m.a.s.l.) where moisture and temperatures are suitable for growing.
The two Eucalyptus species are normally altitude-based with Eucalyptus camaldulensis being adaptable in the upper kolla and woina dega zones that is lower altitudes while Eucalyptus globulus is mostly found in dega and wurch zones meaning higher altitudes. Moreover, its cultivation has gradually spread throughout Ethiopia which is encouraged by academic, research and development institutions including the former Alemaya College of Agriculture, Institute of Agricultural Research (IAR) and Chilalo Agricultural Development Unit (CADU) [9]. Recent studies also highlighted that Eucalyptus is widely planted across Ethiopia including on large areas of land previously allocated to food production [10]. Currently, it is estimated that, over 500000 ha of the land is covered by Eucalyptus plantation in Ethiopia [11].

Though Ethiopian highlands are suffering from severe deforestation and biomass fuel crises, Eucalyptus globulus is the prominent tree in government and community estate plantations because of its fast growth through coppicing, resistance to browsing by livestock, and through simple sawing and potted seedling propagation [12]. Now a day, Ethiopian smallholder farmers have the largest area of Eucalyptus plantations which is more than 0.5 million ha in East Africa [13]. The species contribute $92 \%, 74 \%, 85 \%, 40 \%$, $83 \%$ and $91 \%$ of construction, poles, timber, firewood, charcoal, 
posts and farm implements wood sources for rural Livelihoods respectively [14]. Moreover, most Ethiopian households planted and produced Eucalyptus trees due to its adaptability, fast growth, nonpalatability for livestock and earn high income from sale of Eucalyptus wood product $[12,15]$.

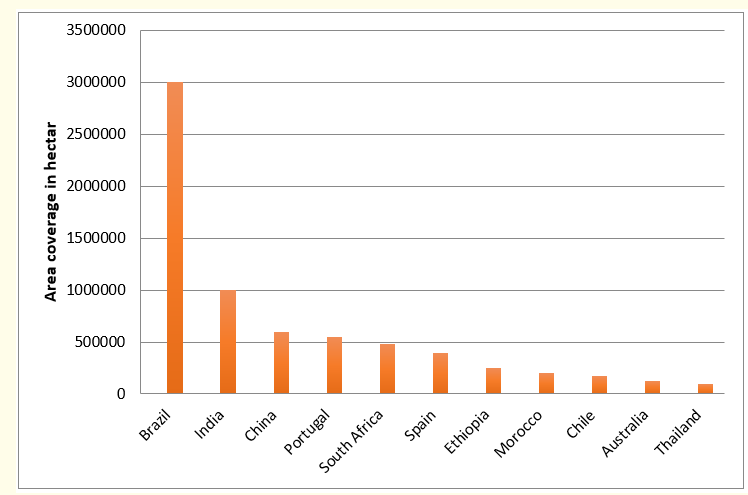

Figure 1: Area coverage of Eucalyptus plantations in some countries.

Source: Turnbull [16].

\section{Forest Development and Eucalyptus Plantation in Ethiopia}

Ohigashi [17] stated that the history of afforestation or modern tree planting in Ethiopia using an exotic species of Eucalyptus was started during the era of Emperor Menelik II at the end of $19^{\text {th }}$ century after he tested more than ten varieties. Forest plantation development in Ethiopia is characterized by the dominance usage of exotic species, such as Eucalyptus globulus which cover about $90 \%$ of the total plantation area, Eucalyptus camaldulensis, cupressus lustanica, casuarinas cunninghamiana, pinus patula, pradiata, and the native species Junipers procera $[18,19]$. The radius of Eucalyptus growing from the capital city Addis Ababa continued to increase during the first decade. The next stage of Eucalyptus growing outside Addis Ababa was by missionaries in Ghimbi, DebreTabor, and Harar. Later, Eucalyptus growing moved to rural areas from these first nodes, being planted first in urban areas, the homesteads and eventually on agricultural lands by farmers and urban dwellers [13].

Eucalyptus plantations have expanded considerably among smallholders and small forestry firms in Ethiopia and placing at the second place in Africa (Figure 1) in terms of area planted with Eucalyptus [13]. Jenbere., et al. [8] also revealed that Eucalyptus species have been introduced in Ethiopia for satisfying the growing demand of wood for fuel, construction material and to reduce the pressure on the remaining natural vegetation. Likewise, the main usage of Eucalyptus in Ethiopia is for firewood and building materials but it has high potential for the production of organic oil particularly Eucalyptus globulus since it is little affected by disease or insect pests [17].
Zerga and Berta [19] stated that Ethiopian farmers were preferred to grow Eucalyptus tree over indigenous tree to cover expenses such as government taxes, fees to schools, money paid as contribution to social organizations such as Mahibers, Zikirs, Iddirs and used for construction purpose at various stages (3 to 4 years for small poles, 5 to 6 years for medium poles, 7 to 8 years for big poles and greater than 9 years logs). Similarly, Tadele., et al. [20] reveled that Eucalyptus plantation played and continues to play significant role in improving the livelihoods of rural communities, poverty reduction and reducing the pressure from remnant native forests in the highlands of Ethiopia.

Moreover, Hailemicael [21] stated that different parts of Eucalyptus have different functions for small scale farmers and poor urban households such as branches, leaves, stems, roots, barks. Branches, roots and leaves are used for fuel wood while the stem can be used either for construction, fuel wood, or transmission poles. Small scale farmers use Eucalyptus for fuel wood, fence and construction of houses or to generate income by selling parts or the whole tree such as Cefeka, Mager, Weraj, Quwami, and fuel wood. In most part of the Ethiopia, all parts of the Eucalyptus trees like stem, bark, branches, leaves, and roots are harvested for daily livelihood activities [22]. Furthermore, Eucalyptus provides wide range of benefits for Ethiopian smallholder farmers providing that it used for fuel wood, construction materials (such as poles and stakes for construction of house, fencing and transmission pole), making of farm equipments, generating income with short period of time, production of charcoal, preventing of soil erosion, shelter belt, drainage and wind break for their fragmented lands [23].

Eucalyptus has a social value as its widespread use create employment opportunity for women and youths in rural areas where there are few other opportunities. Degraded land is common and everywhere in the Ethiopian highlands women and youth plant Eucalyptus on this fragmented land as a means to create opportunity for income generation [24]. Kelemu and Taddesse [25] also revealed that planting of Eucalyptus create job opportunities for females (about 60\%) compared to males starting from seed collection up to the final logging. For example, raising seedlings digging holes, weeding, carrying logs and collection of remains of logs like branches, leaves and barks, are mostly done by females. Even if it is difficult to obtain year-to-year cash income from tree cultivation in general, the average cash income from Eucalyptus over the rotation period is greater than that from other agricultural crops [26].

\section{Environmental and socio-economic implication of Eucalyptus}

Eucalyptus can be cultivated with minimum management activities for different products and services. According to Van Eijck [27], the main cultivation practice needed to produce Eucalyptus were weed control, pruning, fertilization, pest and disease control, harvesting and post harvesting activities. Different literatures revealed that, Eucalyptus species were planted for the first time for the purpose of curiosity in botanic gardens, arboreta (tree collec- 
tions), parks and for amenity. Later on, different stakeholders found that it is valuable trees for fuel wood, charcoal, timber, poles, posts, mine props, plywood, paper pulp, fiber board, production of Eucalyptus oil, shade and shelter, ornamental purposes and as a source of nectar for honey production [16,28]. Similarly, Eldridge., et al. [29] stated that among flowering plants, Eucalyptus is one of the fast growing species in the world that provide various functions. It used for construction material, transmission poles, pulp wood and timber, energy purpose, farm equipment. Hence, Eucalyptus species takes the first place from all exotic species commonly known and planted throughout the world.

Another advantage of Eucalyptus is its performance in degraded lands, swampy area, unfertile and exhausted soil and in dry areas [30] and provision of products with diverse application. According to Ohigashi [17] Eucalyptus is essential woody plants which serve as a raw material for paper pulp, firewood, materials for building houses, furniture, telegraph poles, railroad crossties, pit props, plywood, tar, and extraction of oils as raw material for paints, perfume oils, cosmetics, disinfectants and others. Zerga and Berta [19] also indicated that the main aims of Ethiopian farmers to grow Eucalyptus tree is for the purpose of fuel wood, fencing, farm tool, construction of house, cash income generation, soil and water conservation. Eucalyptus can start providing output from third or fourth year depending on the intention of farmers and type of the product to be extracted if the planting sites have a good condition of nutrient and water. Moreover, Eucalyptus species have been accepted as suitable for shelterbelts and for mixture with agricultural crops in Columbia, Tunisia, Senegal, Nigeria, Cameroon, Pakistan, India, China, Sri Lanka, and Bangladesh [31].

Given the diverse products of Eucalyptus plantation and arguable diverse effects, no single fact should have taken as sufficient evidence either to promote or discourage the planting of the Eucalypts, though results from many studies taken together may yield valid generalizations [24].

\section{The Dilemma of Eucalyptus}

Despite the wide socio-economic and environmental benefits that Eucalyptus renders to world and in Ethiopia too, there are still widely divergent opinions among different stakeholders concerning the advantages and disadvantages of planting Eucalyptus. Some totally oppose its planting, some support it strongly and others have doubts. For instance, Gil., et al. [26] revealed that Eucalyptus has negative impacts when it is planted on wrong sites, done by replacement of existing natural forests coupled with poor management and silvi-culture. On the other hand, it would have positive impacts, which outweigh the negative ones when it is planted on the right sites that are marginal and degraded with good management planning and proper tending.
Eucalyptus species are generally assumed to cause different environmental problems. However, different researchers investigating the positive and negative environmental aspects of Eucalyptus plantations do not have a common agreement on its disadvantages. For instance, Hailemicael [21] stated that the most common important controversies of Eucalyptus are: whether it consumes too much water or not; whether it takes up excess nutrients from the soil or not; whether it decreases the biodiversity in the undergrowth or not and whether it improves the control of soil erosion or not.

Turnbull [16] reveled that it would be necessary to pass legislation to require that almost all charcoal, poles and firewood would be derived from plantations of fast-growing species such as Eucalyptus, to prevent further loss of natural forests. Major arguments that support Eucalyptus planting include: its fast growing; require minimum care; grow in wide ecological zones and poor environments; coppice after harvest; resistant to environmental stress and diseases; it's seeds are easy to collect, store and no pre sowing treatment is required $[14,18]$. Likewise, no other species be it indigenous or exotic, can replace them in the future to bridge the widening gap between demand and supply of wood [16,30]. Similarly, the profit derived from Eucalyptus plantations is considerably higher than cultivating crops [28].

Eucalyptus species played many roles across different countries mostly it accepted as suitable for shelterbelts and for admixture with agricultural crops in Columbia, Tunisia, Senegal, Nigeria, Cameroon, Pakistan, India, China, Sri Lanka, and Bangladesh [31]. Likewise, on the highland verti-soil of Ethiopia Eucalyptus globulus trees are planted in farm boundaries for multiple purposes such as fuel wood, timber, as a cash crop, boundary demarcation, fencing, soil and water conservation, and increasing crop yield [23]. Eucalyptus species can supply wood in good quantities within 4-5 years from comparatively small areas of land [2]. Zegeye [32] also revealed that the benefits of Eucalyptus are far greater than the negative impacts and it provides fuel wood, construction material, charcoal, timber, poles, posts, farm implements, paper pulp, tannin, Eucalyptus oil, nectar for honey production, shade and ornamental purposes.

Furthermore, according to Michelsen., et al. [33], the choice of Eucalyptus species for plantations should be based on many criteria for instance maximum wood production, ecological sustainability, marketability of the planted species (commercial production of timber), and usefulness of the species to the local population. All these criteria involve not only a choice of species planted but also a choice of plantation management methods from initial planting to final harvesting of the trees.

Despite the apparent benefits it provides, it has adverse impact on the environments. Lemenih and Teketay [34] indicated that growing of Eucalyptus increased soil acidity while the base saturation declined compared to native vegetation sites and adjacent 
agricultural lands. Similarly, Negash [35] reported that Eucalyptus has adverse ecological qualities which include depletion of soil water and nutrients, aggressive competition for resources with other plants, production of allopathic chemicals that suppress the growth of other plants, unsuitability for erosion control and incapability of providing adequate food and habitat for wildlife. Furthermore, Eucalyptus plantation are often accused of depleting soil nutrients, reducing soil water reserves, replacing natural forests and threatening ecological stability and diversity since they are often grown in monoculture [2].

Likewise, Okia [36] stated that the Eucalypts have been blamed for many evils, including the drying-up of water courses, the suppression of other vegetation, erosion, and adverse effects on nutrient cycling and soil properties. Moreover, the main arguments against Eucalypts by many researchers includes: it drain water resources; boost soil erosion; suppress undergrowth, deplete soil nutrients; it induce allelophatic effects $[2,9,18]$.

\section{Socio-economic benefits of Eucalyptus}

\section{Citation (Reference)}

- Its Multiple purposes such as Fuel [14,16,18,23,26,30-33] wood, timber, cash crop, boundary demarcation, fencing, soil and water conservation

- Bridge the widening gap between demand and supply of wood

- $\quad$ Shelterbelts

- Fast growing; require minimum care; grow in wide ecological zones and poor environments; coppice after harvest; resistant to environmental stress and diseases; it's seeds are easy to collect, store

Environmental impact of Eucalyptus

- Adverse effect on soil humus, [2,9,18,26,34-36] water, other crops, and wildlife

- $\quad$ Cause soil erosion

Table 1: Summary on dilemma of Eucalyptus woodlot plantation.

\section{Determinants of woodlot plantation and production in Ethiopia}

The main constraints which affect woodlot production were land size, family labor, financial resources, knowledge, technology and the transaction costs and support to the woodlot owners [37]. According to Rapahel and Alemu [38], the performance of forest plantation generally in Ethiopia and particularly in Amhara Region affected by various socio-economic, technical and institutional factors such as lack of extension service, poor market access, lack of cooperation, poor appropriate spacing, thinning, harvesting practice and inadequate institutional and policy support. Likewise, farm size, loan and credit access, per capita income, age of the farmers, land ownership of the farmers, availability of non-agricultural land were some factors which significantly affects farmers' adoption de- cisions on Eucalyptus woodlot production [39].

Abiyu., et al. [40] revealed that the main factor that significantly affect number of tree production and number of tree species were number of livestock owned by the household, land holding size and age of household head. Likewise, the decision to grow trees by smallholder farmer is also affected by market incentives, such as availability of markets for outputs and inputs, their price and associated income loss [41]. Furthermore, Jagger., et al. [42] using ordered probit regression analysis reported that the main determinants of changes in environmental conditions during woodlot establishment were plantation zone, woodlot distance to market, population density, area of woodlot, availability of wasteland, Seedling survival rate, annual precipitation, slopes of area, soil type and tree species.

According to Bekele [43], factors that significantly influence the decision to adopt woodlots as a form of land use were tree tenure security, quality of seed, contact with extension agents and size of land holdings. Woodlots require farmers to set aside part of their land for growing trees that results in the cultivable area under food crops being reduced. Therefore, farmers with smaller plots of land may view tree planting as competing with food crops, thus reducing incentive to establish woodlots.

In the case of Ethiopia, farmers have the ownership right to trees growing on his/her homestead and cultivated lands, but needs to get permission from the local government to cut the trees. This hinders the participation of the farmers in woodlot plantation. Ohigashi [17] also stated that compared to Ethiopian farmers, Thailand farmers operating Eucalyptus plantations own an average of 13 ha of total land and out of 13ha, 8 ha were allocated for $E u$ calyptus but in Ethiopia the average land area owned by farmers are 1.2 ha, with $99 \%$ of farmers owning less than 5 ha of land. Therefore the shortage of land are main constraints for farmers to produce Eucalyptus since it takes a minimum of 5 years to harvest. even though Eucalyptus provides high yield in all ecological conditions, its growth rate depends on different management factors like spacing, site conditions, amount of rainfall [21].

Eucalyptus sale assist smallholder farmers to bridge the food shortage gap at household level. As a result, growing Eucalyptus at a farm level in a form of woodlot has become very common practice among smallholder farmers in rural parts of Ethiopia [24]. However, the size of farm, the wealth status and age of the farmers were the main factors influencing farmers' tree planting activities [44]. Beside this, fertilising is an important factor to increase yield [27]. Likewise, Eucalyptus production was affected by insects (termites, Eucalyptus snout beetle), pests (locus) and fungi [24]. However, Hailemicael [21] reported that compared to other commonly used exotic tree species, Eucalyptus species are not sensitive for the attack of different tree diseases/pathogens/, pests, and environmental stress such as water, and nutrient deficiency due to its genetic diversity by itself has a power to resist such infectious disease and environmental factors. 
The productivity of Eucalyptus in tropical and sub-tropical countries are remained low due to poor genetic stock, weed competition, water stress, low nutrient status of the soil, and threats from pests and diseases [45]. Krause., et al. [46] indicated that the main factors that hinder farmers from growing of woody plants were personal characteristics of farmers, poor access to infrastructure, shortage of land resource and seedlings. Similarly, Githiomi., et al. [47] also revealed that scarcity of seedlings, inadequate land and high cost of establishmen are the main obstacles encountered to farmers in woodlot establishment in centeral kenya.

Hailemicael [21] reported that the main factor that affect the profitability of Eucalyptus plantation in Northern Ethiopia were labour access, low management techniques for wood lots, lack of proper market access and environmental factors like poor soil fertility, rainfall, and rough topography. Similarly, the income and profitability of Eucalyptus tree commercialization by farmers are affected by technical, financial and awareness support; market mechanism; wood price and non-income gains [14]. Even though Eucalyptus is mostly planted everywhere in Ethiopia, its processing and marketing are not linked well due to poor coordination and cooperation among producers. Moreover, lack of knowledge and experiences during sawing, drying and processing of the various commodities produced for the wood of Eucalyptus were the main reason $[48,49]$.

\begin{tabular}{|c|c|c|}
\hline $\begin{array}{l}\text { Factors or attributes } \\
\text { and its Effect on } \\
\text { woodlot production } \\
\text { (+ve or -ve) }\end{array}$ & Description & $\begin{array}{c}\text { Citation } \\
\text { (Reference) }\end{array}$ \\
\hline $\begin{array}{l}\text { Socio-economic and } \\
\text { demographic factors }\end{array}$ & $\begin{array}{l}\text { Lack of cooperation } \\
\text { among producers }\end{array}$ & {$[38,49]$} \\
\hline $\begin{array}{l}\text { Land size orwaste land } \\
(+v e)\end{array}$ & $\begin{array}{l}\text { Availability large land } \\
\text { size and waste land }\end{array}$ & {$[37,39,40,42]$} \\
\hline Wood price(-ve) & $\begin{array}{l}\text { Lower price of prod- } \\
\text { uct }\end{array}$ & {$[14]$} \\
\hline Family labour(+ve) & Large family size & {$[37]$} \\
\hline Age & $\begin{array}{l}\text { Elder HH produce } \\
\text { more woodlot since it } \\
\text { less costly and labour } \\
\text { intensive }\end{array}$ & {$[39,40,48]$} \\
\hline $\begin{array}{l}\text { Physical factors(-ve) } \\
\text { - } \quad \text { Soil fertility, } \\
\text { - } \quad \text { Weed, } \\
\text { - } \quad \text { Insects and pests } \\
\text { - } \quad \text { Rainfall }\end{array}$ & $\begin{array}{l}\text { Poor soil fertil- } \\
\text { ity weed competition, } \\
\text { excess or little rainfall }\end{array}$ & {$[24,45]$} \\
\hline $\begin{array}{l}\text { Institutional factors } \\
\text { (-ve) } \\
\text { - } \quad \text { Market access } \\
\text { - } \quad \text { Extension service } \\
\text { access } \\
\text { - } \quad \text { Policy support } \\
\text { - } \quad \text { Infrastructure }\end{array}$ & $\begin{array}{l}\text { Poor access of mar- } \\
\text { ket, extension and in- } \\
\text { frastructure like road } \\
\text { as well as inadequate } \\
\text { institutional and pol- } \\
\text { icy support of forest } \\
\text { plantation }\end{array}$ & {$[14,38,21,41]$} \\
\hline
\end{tabular}

Table 2: Summary of factors affect woodlot production.

\section{Conclusion}

In Ethiopia, afforestation (tree planting) was started in the early 1400s. But modern tree planting using an exotic tree species mainly Australian Eucalyptus were started in 1895 to alleviate the shortage of firewood and construction wood in the capital city of Ethiopia. Eucalyptus plantation is widely established and planted throughout Ethiopia on large areas of land which previously allocated to crop production. Currently, it is estimated that, more than 500,000 ha of the land is covered by Eucalyptus plantation for various purpose in Ethiopia. In the country, the demand of Eucalyptus increased from time to time due to its adaptability, fast growth, non-palatability for livestock and earn high income from sale of Eucalyptus wood product. Though there dilemma on Eucalyptus plantation among scientists, the positive impact of Eucalyptus plantation is higher than its negative impact. Generally, there is no any profound reason not to continue Eucalyptus plantation in Ethiopia. Therefore, to maximize its socio-economic benefits and minimize its negative impact on soil, water and neighbor crop, cluster planting and using appropriate management methods such as spacing, species and site selection are advisable. Moreover, to reduce the natural forest deforestation, planting and expanding of Eucalyptus in the form of woodlot are advisable.

\section{Bibliography}

1. Rassaeifar M., et al. "Allelopathic effect of eucalyptus globulus essential oil on seed germination and seedling establishment of Amaranthus blitoides and Cyndon dactylon". Trakia Journal of Sciences 11.1 (2013): 73-81.

2. Teketay D., "Facts and experiences on Eucalypts in Ethiopia and elsewhere: Ground for making life informed decisions". Walia 21 (2000): 25-46.

3. Kilimo T. "Eucalyptus Hybrid Clones in East Africa; Meeting the Demand for Wood through Clonal Forestry Technology". Occassional Paper No.1 (2011).

4. Liu H and Li J. "The study of the ecological problems of eucalyptus plantation and sustainable development in Maoming Xiaoliang". Journal of Sustainable development 3.1 (2010): 197.

5. Oballa P., et al. "The performance of Eucalyptus Hybrid clones and local landraces in Various agro-ecological zones in Kenya". International Service for the acquisition of Agri-Biotechnology Applications (ISAA) (2005).

6. Tadesse M. "Flora of Ethiopia and Eritrea". Addis Abeba University, Ethiopia (2005).

7. Kebebew $\mathrm{Z}$ and Ayele G. "Profitablity and household income contribution of growing Eucalyptus globules(Labill) to smallholder farmers: the case of central highland of Oromia, Ethiopia". European Journal of Forest Research 2.1 (2010): 25-29. 
8. Jenbere D., et al. "Expansion of eucalypt farm forestry and its determinants in Arsi Negelle District, South Central Ethiopia". Small-scale Forestry 11.3 (2012): 389-405.

9. Getahun A. "Eucalyptus farming in Ethiopia: the case for eucalyptus woodlots in the Amhara region". AGRIS (2003).

10. Liang J., et al. "Effects of exotic Eucalyptus spp. plantations on soil properties in and around sacred natural sites in the northern Ethiopian Highlands". AIMS Agriculture and Food 1.2 (2016): 175-193.

11. Abebe M and Tadesse W. "Eucalyptus in Ethiopia: Risk or Opportunity?". Ethiopian Institutes of Agricultural Research, Addis Ababa, Ethiopia (2014): 65.

12. Zewdie M. "Temporal changes of biomass production, soil properties and ground flora in Eucalyptus globulus plantations in the central highlands of Ethiopia" 2008.18 (2008).

13. Getahun A. "Eucalyptus farming in Ethiopia: The case of Eucalyptus farm and village woodlots in Amhara Region". Gil, Wubalem, Tolosana, and Lopez (eds). Eucaluptus Species Management, History, Status and Trends in Ethiopia (2010): 206-221.

14. Mekonnen Z., et al. "The role and management of eucalyptus in Lode Hetosa district, Central Ethiopia". Forests, Trees and Livelihoods 17.4 (2007): 309-323.

15. Dessie A B., et al. "Analysis of Smallholder Farmers' Cooperation in Eucalyptus Woodlot Production in Wegera District, Northern Ethiopia". Small-scale Forestry (2019): 1-18.

16. Turnbull J W. "Eucalypt plantations". In Planted Forests: Contributions to the Quest for Sustainable Societies Springer Netherlands (1999): 37-52.

17. Ohigashi H. "Utilization and production of medicinal plants. Medicinal crops in Ethiopia Current status and future potential". (Makiu ed.). JAICAF (Japan Association) (2008).

18. FAO. "The Socio-Economic and Environmental Issues of Eucalyptus in Eastern Africa." Adiss Abeba, Ethiopia (2009): 46.

19. Zerga B and Berta A. "Preference, Purpose, and Pattern of Eucalyptus tree Farming in Eza Wereda, Ethiopia”. IJRIES 3.2 (2016): 30-38.

20. Tadele D., et al. "Effect of Eucalyptus camaldulensis stand Conversion into Crop Production on Growth and Yield of Maize: the case of Koga Watershed Areas in northwestern Ethiopia". Ethiopian Journal of Science 6.1 (2014): 58-69.

21. Hailemicael B K. "The Contribution of Eucalyptus Woodlots to the Livelihoods of Small Scale Farmers in Tropical and Subtropical Countries with Special Reference to the Ethiopian Highlands". (2012).
22. Daba M. "The Eucalyptus Dilemma: The Pursuit for Socio-economic Benefit versus Environmental Impacts of Eucalyptus in Ethiopia" Journal of Natural Sciences Research 6.19 (2016): $127-131$.

23. Kidanu S. "Using Eucalyptus for soil \& water conservation on the highland vertisols of Ethiopia" (2004).

24. Jagger $P$ and Pender J. "The role of trees for sustainable management of less-favored lands: the case of eucalyptus in Ethiopia". Forest Policy and Economics 5.1 (2003): 83-95.

25. Kelemu K and Tadesse W. "Analysis of Eucalyptus role in the livelihoods of rural households. Eucalyptus Species Management, History, Status and Trends in Ethiopia". Addis Ababa: ETH-CANA publishing company (2010): 53-61.

26. Gil L., et al. "Eucalyptus species management, history, status and trends in Ethiopia". Proceedings from the Congress held in Addis Ababa (2010): 335-350.

27. Van Eijck J A J. "Socio-economic impacts of biofuels in developing countries (Doctoral dissertation, Uitgeverij BOXPress)" (2014).

28. Pohjonen V and Pukkala T. "Profitability of establishing Eucalyptus globulus plantations in the Central Highlands of Ethiopia” 22.4 (1988).

29. Eldridge S R., et al. "Health and structure of Eucalyptus communities on Chowilland and Monoman Islands of the River Murray floodplain, South Australia". (1993).

30. Pohjonen V and Pukkala T. "Which eucalypt grows best in Ethiopian highlands?". Biomass and Bioenergy 1.4 (1991): 193198.

31. Ahmed R., et al. "Eucalyptus as agroforestry component in the homestead and agricultural field of Sitakunda, Bangladesh". Sustainable Agricultural Technology 3.3 (2007): 46-51.

32. Zegeye H. "Environmental and socioeconomic implications of Eucalyptus in Ethiopia". Eucalyptus Species Management, History, Status and Trends in Ethiopia. Addis Ababa: ETH-CANA publishing company (2010): 184-205.

33. Michelsen A., et al. "Comparisons of understorey vegetation and soil fertility in plantations and adjacent natural forests in the Ethiopian highlands". Journal of Applied Ecology (1996): 627-642.

34. Lemenih M and Teketay D. "Restoration of native forest flora in the degraded highlands of Ethiopia: constraints and opportunities". SINET: Ethiopian Journal of Science 27.1 (2004): 75-90.

35. Negash L. "The Tortuous Path Ahead: How Man is Destroying his Earth". Dryland Biodiversity Newsletter 3 (1999): 9-12. 
36. Okia C A. "Eucalyptus: a blessing or a curse for Africa?". Department of Community Forestry and Extension, Makerere University, Uganda (2009).

37. Maningo E V. "Contribution Of Family Woodlots On Livelihoods Of Rural Communities" (2014).

38. Rapahel B and Alemu A. "Evaluation of the construction wood and fuel wood value chain from Amhara Region, Ethiopia". GIZ Technical Report. Forest and Biodiversity Program, Addis Abeba, Ethiopia (2016).

39. Tefera S A and Lerra M D. "Determinants of Farmers Decision Making for Plant Eucalyptus Trees in Market District, North Willow, Ethiopia" (2016).

40. Abiyu A., et al. "Spatial patterns and determinants of smallholder tree planting in Northwest Highlands of Ethiopia". JAD 2.2 (2012): 25.

41. Arnold J M., et al. "Woodfuels, livelihoods, and policy interventions: changing perspectives". World development 34.3 (2006): 596-611.

42. Jagger P., et al. "Woodlot devolution in Northern Ethiopia: Opportunities for empowerment, smallholder income diversification, and sustainable land management". International Food Policy Research Institute 107 (2003).

43. Bekele M. "Forest plantations and woodlots in Ethiopia". In Afr For Forum Work. Pap. Ser 1 (2011): 1-51.

44. Bongers G. "Dynamics in people-tree interactions in farm fields, farmers' perspectives in Meskan district, Ethiopia". Wageningen University, Netherlands (2010).

45. Kallarackal J and Somen C K. "Water use by Eucalyptus tereticornis stands of differing density in southern India". Tree Physiology 17.3 (1997): 195-203.

46. Krause M., et al. "Decision modelling for the integration of woody plants in smallholder farms in the central highlands of Ethiopia". Journal of Agriculture and Rural Development in the Tropics and Subtropics (JARTS) 108.1 (2007): 1-17.

47. Githiomi J K and Mugendi D N. "Household tree planting and its related constraints in meeting woodfuel production in Kiambu, Thika and Maragwa Districts of Central Kenya". Journal of Horticulture and Forestry 4.7 (2012): 120-125.

48. Bekele T. "Kiln drying of sawn boards of young Eucalyptus globulus Labill. and Eucalyptus camaldulensis Dehnh, grown on the Ethiopian Highlands". European Journal of Wood and Wood Products 52.6 (1994): 377-382.
49. Dessie A B., et al. "Determinants of the production and commercial values of Eucalyptus woodlot products in Wogera District, Northern Ethiopia". Environmental Systems Research 8.1 (2019): 4.

Volume 3 Issue 9 September 2019

(C) All rights are reserved by Abebe Birara Dessie., et al. 